\title{
GAMBARAN KADAR KOLESTEROL LOW DENSITY LIPOPROTEIN (LDL) PADA MASYARAKAT PEROKOK DI PESISIR PANTAI
}

\author{
${ }^{1}$ Aji M. Sanhia \\ ${ }^{2}$ Damajanty H. C. Pangemanan \\ ${ }^{2}$ Joice N. A. Engka \\ ${ }^{1}$ Kandidat Skripsi Fakultas Kedokteran Universitas Sam Ratulangi Manado \\ ${ }^{2}$ Bagian Fisiologi Fakultas Kedokteran Universitas Sam Ratulangi Manado \\ Email: Ajimuftisanhia2@yahoo.com
}

\begin{abstract}
Low Density Lipoprotein (LDL) is a type of lipoprotein that transports cholesterol most widely in the body. Smoking is one of the factors that can cause elevated levels of LDL cholesterol, which nicotine is one element in cigarettes cathecolamine that stimulates secretion, increases lipolysis, and also increases free fatty acids. Excessive levels of LDL cholesterol in the blood will increase the risk of cholesterol buildup in the arteries, followed by atherosclerosis. This study aimed to describe the levels of LDL cholesterol in seashores community smoker. This was a descriptive analysis with a cross sectional design. Samples in this study were 40 people. The results showed that the mean LDL cholesterol level of 40 samples was $132.93 \mathrm{mg}$ / dl which 24 sample (60\%) was at the above the borderline threshold. There was no subject with high LDL level. Conclusion: There was an increase in LDL level in smokers who lived in seashores.
\end{abstract}

Keywords: low density lipoprotein (LDL), smokers.

\begin{abstract}
Abstrak: Low Density Lipoprotein (LDL) merupakan jenis lipoprotein yang paling banyak mengangkut kolesterol di dalam tubuh. Merokok merupakan salah satu faktor yang dapat menyebabkan terjadinya peningkatan kadar kolesterol LDL, dimana nikotin yang merupakan salah satu unsur pada rokok merangsang sekresi katakolamin, meningkatkan lipolisis, dan meningkatkan asam lemak bebas. Kadar kolesterol LDL yang berlebihan dalam darah akan meningkatkan resiko penumpukan kolesterol pada dinding pembuluh darah arteri yang diikuti dengan terjadinya aterosklerosis. Penelitian ini bertujuan untuk mengetahui gambaran kadar kolesterol LDL pada masyarakat di pesisir pantai. Penelitian yang digunakan bersifat deskriptif analisis dengan rancangan Cross Sectional Study. Sampel dalam penelitian ini berjumlah 40 orang yang sesuai kriteria inklusi dan bersedia menjadi responden. Hasil penelitian memperlihatkan tingkat kolesterol LDL rata-rata pada 40 sampel ialah 132,93 mg/dl, dengan 24 sampel (60\%) berada di atas ambang batas dan sisanya memiliki kadar LDL di bawah ambang batas. Simpulan: Terdapat peningkatan kadar LDL pada perokok yang tinggal di pesisir pantai.
\end{abstract}

Kata kunci: low density lipoprotein (LDL), perokok.

Kolesterol merupakan lipid amfipatik membentuk komponen struktural esensial yang terdapat pada lapisan eksternal membran sel dan merupakan lipoprotein plasma. Lipoprotein mengangkut kolesterol bebas di dalam sirkulasi darah, tempat unsur ini segera mengimbangi unsur kolesterol pada lipoprotein lainnya dan membran sel. Empat kelompok utama lipoprotein telah berhasil diketahui yaitu Trigleserida, Very Low Density Lipoprotein (VLDL), Low Density Lipoprotein (LDL), 
High Density Lipoprotein (HDL). ${ }^{1}$

Kolesterol dapat ditemukan dari berbagai makanan seperti daging sapi, kambing, babi, ayam, dan ikan. Kolesterol sangat diperlukan untuk berbagai macam fungsi, seperti dalam pembuatan hormone, membentuk dinding sel dan lain-lain. ${ }^{2}$

Sekitar separuh kolesterol tubuh dibuat oleh tubuh sendiri dan sisanya diperoleh dari makanan yang kita makan sehari-hari. Hepar dan usus masing-masing menghasilkan sekitar $10 \%$ dari sintesis total pada manusia. Hampir semua jaringan yang memiliki sel berinti dapat membentuk kolesterol, yang berlangsung di retikulum endoplasma dan sitosol. ${ }^{3}$

Kebiasaan merokok merupakan salah satu faktor peningkatan kadar kolesterol dalam darah. Banyak orang yang mengaku tahu akan dampak buruk merokok bagi kesehatan, namun mereka tidak mengetahui bahwa asap rokok dapat meningkatkan kadar LDL di dalam tubuh mereka. Zat kimia yang terkandung dalam rokok dapat meningkatkatkan kadar kolesterol jahat (LDL) dan menurunkan kadar kolesterol baik ( HDL) dalam tubuh manusia. Pada orang-orang yang merokok ditemukan kadar HDL yang rendah, artinya pembentukan kolesterol baik yang bertugas membawa lemak dari jaringan ke hati menjadi terganggu. Sementara kebalikannya justru terjadi pada kadar LDL, dimana pada orang yang merokok ditemukan kadar LDL yang tinggi, artinya lemak dari hati justru dibawa kembali ke jaringan tubuh.

Peningkatan kadar LDL dalam darah dapat menyebabkan Penyakit Jantung Koroner (PJK). PJK masih menjadi salah satu penyakit yang mematikan saat ini, baik di negara maju ataupun negara berkembang. Menurut data dari World Health Organization (WHO), pada tahun 2008 sekitar 17,3 juta atau setara dengan $30 \%$ kematian di seluruh dunia disebabkan oleh penyakit jantung dan pembuluh darah. Dari angka kematian diatas diperkirakan 7,3 juta disebabkan oleh PJK dan 6,2 juta disebabkan karena penyakit stroke. Pada tahun 2030 diperkirakan angka kematian tersebut akan meningkat menjadi 25 juta. ${ }^{4}$

Di Amerika Serikat setiap tahun 550.000 orang meninggal karena penyakit ini. Di Eropa diperhitungkan 20.000 40.000 orang dari satu juta penduduk menderita PJK. Survei yang dilakukan Departemen Kesehatan RI menyatakan prevalensi PJK di Indonesia dari tahun ke tahun terus meningkat. Persentase kematian akibat penyakit jantung dari total angka kematian menunjukkan peningkatan dari 5,9\% pada 1975 menjadi 26,4\% pada 2004. Data yang diperoleh dari Jakarta Cardiovascular Study pada 2008 memperlihatkan prevalensi infark miokard pada wanita $4,12 \%$ dan $7,6 \%$ pada pria, atau 5,29\% secara keseluruhan. Terjadi peningkatan dibanding tahun 2000 yang hanya $1,2 \%$. Peningkatan selama 7 tahun sebesar $4,09 \%$ atau rata-rata $0,6 \%$ setiap tahun. ${ }^{4}$

Tujuan penelitian ini untuk mendapatkan gambaran kadar Kolesterol Low Density Lipoprotein (LDL) pada masyarakat perokok di pesisir pantai.

\section{METODE PENELITIAN}

Jenis penelitian yang digunakan adalah bersifat deskriptif analisis dengan rancangan Cross Sectional Study.

Penelitian ini dilaksanakan di pesisir pantai Malalayang. Pemeriksaan sampel darah dilakukan di Laboratorium. Populasi adalah Masyarakat perokok di pesisir Kota Manado. Pengambilan sampel menggunakan metode purposive sampling. Sampel ialah bagian dari populasi yaitu masyarakat perokok berjumlah 40 orang yang ada di pesisir pantai Malalayang yang memenuhi kriteria: Laki - laki $\geq 18$ tahun, perokok aktif minimal 1 tahun, banyak rokok minimal 4-5 batang sehari, penduduk yang menetap 5 tahun.

Instrumen penelitian yang dipakai adalah KIT untuk mengukur kadar kolesterol LDL, jarum suntik, tourniquet, sampel darah, alcohol, dan reagen untuk pemeriksaan kadar kolesterol LDL.

Sampel diambil dengan cara 
mengambil darah pada pembuluh darah vena pada lipat siku (fossa cubiti). Setelah itu sampel darah tersebut di masukkan kedalam tabung sampel darah untuk di bawa ke laboratorium pro kita untuk di periksa kadar LDL dalam darah.

\section{HASIL DAN BAHASAN}

Penelitian yang dilakukan pada masyarakat perokok dipesisir pantai malalayang yang bertujuan untuk mengetahui bagaimana gambaran kadar LDL darah pada masyarakat perokok dipesisir pantai yang berjenis kelamin lakilaki dengan usia $\geq 18$ tahun dengan jumlah responden sebanyak 40 orang.

Table 1. Derajat Pengukuran kadar LDL

\begin{tabular}{cccc}
\hline Klasifikasi & Kadar & $\mathrm{n}$ & $\%$ \\
\hline Optimal & $<100$ & 3 & 7,5 \\
Hampir & $100-129$ & 13 & 32.5 \\
Ambang & $130-159$ & 24 & 60 \\
Tinggi & $160-189$ & 0 & 0 \\
Sangattinggi & $>190$ & 0 & 0 \\
\hline Total & & 40 & 100 \\
\hline
\end{tabular}

Dari Tabel 1 didapatkan kadar LDL dari 40 orang sampel, klasifikasi paling banyak berada pada ambang batas atas yaitu sebanyak 24 orang sampel atau sebanyak $60 \%$ dari total sampel. Klasifikasi paling sedikit ditemukan ialah kadar LDL optimal yaitu sebanyak 3 orang atau sebesar $7,5 \%$ dari total sampel. Sebanyak 13 orang sampel yang tersisa berada pada klasifikasi kadar LDL hampir optimal atau sebanyak 32,5\% dari total sampel.

Penelitian berdasarkan teori bahwa merokok dapat meningkatkan kadar kolesterol LDL. Kolesterol adalah steroid yang terutama dijumpai pada binatang dan sangat jarang pada tumbuh-tumbuhan. Kolesterol merupakan makanan utama manusia dan juga disintesa dalam tubuh, senyawa ini merupakan makanan prekursor yang penting dari hormon streoid dan asam empedu, suatu pengemulsian lemak yang dikeluarkan ke dalam usus halus. Kadar kolesterol dalam aliran darah dipengaruhi oleh banyak faktor termasuk diet dan metabolisme makanan dalam tubuh.

Karbon monoksida (CO) dapat mengakibatkan terjadinya kekurangan oksigen dan merusak pembuluh darah maupun penyempitan sampai pada penutupan. Rokok mengandung banyak unsur yang berbahaya, diantaranya adalah nikotin yang berpengaruh pada kerja jantung, meningkatkan penggumpalan darah dan akhirnya meningkatkan kadar kolesterol LDL darah dan menurunkan kadar kolesterol HDL darah. Pada perokok, nikotin dipercaya mengontribusi pada abnormalitas profil lipid. Efek nikotin, hampir secara keseluruhan melepaskan katekolamin, meningkatkan lipolisis, dan meningkatkan asam lemak bebas. Dengan meningkatnya asam lemak bebas membuat produksi kolesterol LDL yang berlebihan dan dengan produksi LDL yang berlebihan maka kadar kolesterol HDL darah dengan sendirinya akan menurun.

Pada penelitian yang dilakukan oleh Pugalendi KV dan Ramakrishnan S 1991 tentang Blood cholesterol and HDL cholesterol in smokers, yang dilakukan pada 24 perokok dengan jenis kelamin sama ditemukan terjadi penurunan kadar HDL pada 21 perokok. Mekanisme peningkatan kolesterol darah adalah melalui peningkatan asam lemak bebas dari darah Pada perokok nikotin merangsang sekresi katekolamin. Hormon ini meningkatkan FFA oleh lipolisis lemak jaringan adiposa. FFA yang mencapai hati diesterifikasi sebagai triasilgliserol dan ester kolesterol yang disekresikan ke dalam aliran darah sebagai VLDL yang akan dikonversi menjadi LDL yang beredar dalam darah. ${ }^{5}$

Meningkatnya kadar LDL disebabkan bahan kimia tertentu yang ditemukan dalam asap rokok, salah satunya akrolein. Akrolein dapat merusak HDL sehingga mengganggu tugas HDL dalam mengumpulkan kolesterol jahat atau LDL. Merokok Meningkatkan Kadar LDL Penurunan kadar HDL memungkinkan LDL untuk menumpuk dan bergerak bebas 
dalam aliran darah. Akrolein memicu proses yang mengubah struktur molekul LDL sehingga membuatnya menjadi tidak dikenali oleh sistem kekebalan tubuh.

Sistem kekebalan tubuh mengeluarkan sel-sel darah putih untuk menyerang LDL, yang menyebabkan peradangan dan kemudian terakumulasi. Akumulasi ini akan menyebabkan penumpukan plak pada dinding arteri, yang kemudian mengeras seiring berjalannya waktu dan menyebabkan aterosklerosis

Tabel 2. Distribusi Kadar LDL Menurut Umur

\begin{tabular}{ccc}
\hline Umur & $\mathrm{n}$ & $\begin{array}{c}\text { Rerata Kadar LDL } \\
(\mathrm{mg} / \mathrm{dl})\end{array}$ \\
\hline $18-22$ & 5 & 138,69 \\
$23-27$ & 9 & 127,02 \\
$28-32$ & 12 & 134,51 \\
$33-37$ & 8 & 132,99 \\
$38-42$ & 6 & 133,78 \\
\hline Total & 40 & 132,93 \\
\hline
\end{tabular}

Berdasarkan data diatas kelompok umur 18-22 tahun memiliki rerata kadar LDL sebanyak 138,69 mg/dl, sedangkan pada kelompok umur 23-27 tahun memiliki rerata $127,02 \mathrm{mg} / \mathrm{dl}$, dengan rerata total sebanyak 132,93 $\mathrm{mg} / \mathrm{dl}$.

Sesuai data Tabel 3 sampel yang mengkonsumsi rokok $\leq 10$ memiliki rerata kadar LDL sebanyak 123,39 mg/dl, dan sampel yang mengkonsumsi rokok >20 memiliki rerata kadar LDL sebanyak $143,65 \mathrm{mg} / \mathrm{dl}$, dengan rerata total 132,93 $\mathrm{mg} / \mathrm{dl}$.

Tabel 3. Distribusi Kadar LDL Menurut Jumlah Rokok

\begin{tabular}{ccc}
\hline Jumlah Rokok & $\mathrm{n}$ & $\begin{array}{c}\text { Rerata Kadar LDL } \\
(\mathrm{mg} / \mathrm{dl})\end{array}$ \\
\hline$\leq 10$ & 13 & 123,39 \\
$11-20$ & 13 & 130,93 \\
$>20$ & 14 & 143,65 \\
\hline Total & 40 & 132,93 \\
\hline
\end{tabular}

Jumlah rokok yang di konsumsi sampel juga menyebabkan peningkatan kadar kolesterol LDL, ini sesuai dengan penelitian yang di lakukan oleh NS Neki tahun 2002 tentang Lipid Profile in Chronic Smokers, yang dilakukan pada 50 perokok rokok sehat dan dibandingkan dengan 50 usia yang sehat dan berat badan yang cocok non-obesitas non-perokok sebagai kontrol. Subjek dalam kedua kelompok berada di kisaran usia 25-35 thn. Selanjutnya, subjek merokok dengan jumlah rokok $11-20$ per hari memiliki kadar kolesterol HDL (41,2 \pm 5,80 mg / dl) lebih rendah dibandingkan dengan mereka yang merokok 1-10 batang yang memiliki kadar HDL (44,6 \pm 6,09 mg / dl). Temuan ini menunjukan bahwa merokok mengubah profil lipid yang menyebabkan dyslipidemia pada perokok dan tanda perubahan lebih banyak didapati pada perokok dengan jumlah rokok tinggi. Merokok menyebabkan peningkatan oksidasi kolesterol LDL yang merupakan peran kunci pada aterosklerosis. Kadar kolesterol LDL yang tinggi menyebabkan penurunan kadar kolesterol HDL yang merupakan preindikator independen dari penyakit arteri koroner. ${ }^{6}$

Berdasarkan data Tabel 4 sampel yang merokok selama 1 tahun memiliki rerata kadar LDL sebanyak $118.65 \mathrm{mg} / \mathrm{dl}$, sedangkan sampel yang merokok selama 3 tahun memiliki rerata kadar LDL sebanyak $143.88 \mathrm{mg} / \mathrm{dl}$, dengan rerata total sebanyak $132.93 \mathrm{mg} / \mathrm{dl}$. Pada penelitian yang dilakukan Neal L Benowitz tahun 1997 tentang Cardiovascular Toxicity of Nicotine: Implications for Nicotine Replacement Therapy.

Table 4. Distribusi Kadar LDL Menurut Waktu Merokok

\begin{tabular}{ccc}
\hline $\begin{array}{c}\text { Jangka Waktu } \\
\text { (tahun) }\end{array}$ & $\mathrm{n}$ & $\begin{array}{c}\text { Rerata Kadar LDL } \\
(\mathrm{Mg} / \mathrm{dl})\end{array}$ \\
\hline 1 & 13 & 118,65 \\
2 & 12 & 134,74 \\
3 & 15 & 143,88 \\
\hline Total & 40 & 132,93 \\
\hline
\end{tabular}

Nikotin merupakan salah satu unsur 
utama dalam rokok. Nikotin menyebabkan peningkatan kadar trigliserida, kolesterol,dan VLDL, serta penurunan kadar HDL. Konsumsi nikotin jangka panjang dapat meningkatkan kolesterol LDL dan penurunan kolesterol HDL.

Merokok berhubungan dengan peningkatan produksi radikal bebas dan deplesi antioksidan. Radikal bebas menyebabkan kerusakan oksidatif pada beberapa makromolekul seperti lipid, protein, dan DNA, sehingga berperan penting dalam beberapa penyakit kronis seperti aterosklerosis dan kanker. HDL (kolesterol baik) bertanggung jawab mengumpulkan kelebihan LDL (kolesterol jahat) dalam aliran darah dan mengangkutnya kembali ke hati untuk dibuang. ${ }^{7}$

Penelitian oleh Jung-Mun Noh tahun 2012 Changes in the serum Level of High Density Lipoprotein-cholesterol after Smoking Cessation among Adult Men, dengan sampel sebanyak 779 laki-laki usia 25 tahun atau lebih tua yang memiliki pemeriksaan pemeriksaan kesehatan dua kali pada tahun 2007 dan tiga tahun kemudian pada tahun 2010 di pusat promosi kesehatan Daegu Medical Center. ${ }^{2}$ Informasi tentang karakteristik umum dan riwayat merokok dikumpulkan melalui survei. Mereka yang tidak menyatakan perilaku yang berhubungan dengan kesehatan seperti merokok, atau tidak jelas (307 individu), dikeluarkan. Non-perokok, mantan abstain (273 individu), orang-orang dengan penyakit (kanker, diabetes, penyakit kelenjar tiroid, TB aktif, penyakit kronis, dan lain-lain) yang mungkin mempengaruhi berat badan atau lipid profil dan orang-orang yang memakai obat (15 orang ) dikeluarkan. Jumlah subjek akhir adalah 184. Di antara sampel, menunjukkan peningkatan yang signifikan dalam berat badan setelah tiga tahun khususnya yang berusia lebih tua, peningkatan berat badan ini disebabkan karena penumpukan kadar kolesterol LDL yang tinggi sehingga menyebabkan penurunan kadar serum HDL-kolesterol setelah tiga tahun, beberapa penelitian menyatakan bahwa merokok memfasilitasi sekresi katekolamin dan secara drastis meningkatkan asam lemak bebas, yang mengarah ke peningkatan kolesterol LDL dan penurunan HDL-kolesterol pada waktu yang sama. ${ }^{8}$

\section{SIMPULAN}

Dari hasil penelitian disimpulkan bahwa terdapat peningkatan kadar kolesterol LDL pada perokok yang tinggal di pesisir pantai.

\section{DAFTAR PUSTAKA}

1. Mayes PA. Sintesis, Pengangkutan, dan Ekskresi Kolesterol. Dalam : Muray RK, Granneer DK, Mayes PA, Rodwel VW, Editor. Biokimia Harper. Edisi ke-25. Alih Bahasa : Hartono A. Jakarta: EGC; 2001. p. 270-281.

2. Soeharto I. Penyakit Jantung Koroner dan Serangan Jantung. Edisi ke-2. Jakarta: Gramedia Pustaka Utama; 2004. p. 63-85.

3. Botham KM, Mayes PA. Sintesis, Transport, \& Ekskresi Kolesterol. Dalam : Muray RK, Granneer DK, Rodwel VW, Editor. Biokimia Harper. Edisi ke-27. Alih Bahasa : Pendit BU. Jakarta: EGC; 2006. p. 239-249.

4. WHO. Cardio Vascular Disease. 2011. Available from : http://www.who.int/mediacentre/facts heets/fs317/en/index.html Access on : 22 September 2013.

5. Pugalendi KV, Ramakrishnan S. Blood Cholesterol and HDL Cholesterol in Cigarette Smokers From : http://www.ijpp.com/IJPP\%20archive s/1991_35_2/138-140.pdf

6. NS Neki. Lipid Profile in Chronic Smokers - A Clinical Study. From: medind.nic.in/jac/t02/i1/jact02i1p51.p df

7. Neal L, Steven G. Cardiovascular Toxicity of Nicotine: Implications for Nicotine Replacement Therapy from : http://content.onlinejacc.org/article.as px?articleid $=1121737$.

8. Jung $M$, Seock $H$, Hyun $W$, Hong S. Changes in the serum Level of High 
Sanhia, Pangemanan, Engka: Gambaran kadar kolesterol...

Density Lipoprotein-cholesterol after Smoking Cessation among Adult Men From http://www.ncbi.nlm.nih.gov/pmc/arti cles/PMC3481030/ 